\title{
DNA Isolation from Desiccated Leaf Material for Plum Tree (Prunus domestica L.) Molecular Analysis
}

\author{
Monica BODEA, Doru PAMFIL, Rodica POP, Cristian Radu SISEA* \\ University of Agricultural Sciences and Veterinary Medicine Cluj-Napoca, Calea Mănăştur 3-5, 400372 \\ Cluj-Napoca, Romania. \\ *)Corresponding author, e-mail: cristisisea@yahoo.com
}

BulletinUASVM Horticulture 73(1) / 2016

Print ISSN 1843-5254, Electronic ISSN 1843-5394

DOI:10.15835/buasvmcn-hort:11761

\begin{abstract}
Conservation of biodiversity is very important, especially in species such as plum tree. One of the key aspects is the establishment of appropriate genetic markers that could be used to identify provenances and also for breeding purposes. In this context, molecular characterization using SSR (short sequence repeats) markers is very useful and was chosen for our study. This article describes the assessment of a CTAB-based DNA extraction protocol for isolating and purifying DNA from the plum cultivars selected for molecular characterisation. The quality of DNA extracts was assessed by spectrophotometric measurement and their suitability for molecular analysis was evaluated using a SSR marker system. We concluded that the DNA extraction protocol is suitable for obtaining plum DNA that can be used for molecular analysis using SSR markers.
\end{abstract}

Keywords: plum tree, $\mathrm{CaCl}_{2}$, DNA isolation, CTAB, marker, SSR.

\section{INTRODUCTION}

Conservation of biological diversity is important within each species and especially for economically relevant ones, such as plum tree (Prunus domestica L.), which accounts for more than one third of Romania's fruit trees acreage. In this context, one important aspect is the phenotypical and molecular characterisation of local populations and old, traditional cultivars. Identified markers should firstly constitute an effective means for identification of each provenance and they could also prove very useful in any breeding applications.

\section{AIM AND OBJECTIVES}

The aim of our project is to create a database comprising phenotypic and SSR-derived (short sequence repeats) molecular characteristics of Romanian plum tree cultivars. One of the key objectives is the proper isolation of DNA from all plum tree cultivars in order for the SSR analysis to be performed. The establishment and optimization of this procedure for our study is described here.

\section{MATERIALS AND METHODS}

The 70 plum tree cultivars selected for SSR analysis (Table 1) are part of the SDPV Vâlcea collection (Râmnicu Vâlcea, Romania). Fresh leaves obtained from each cultivar were incubated for approximately two weeks at $4{ }^{\circ} \mathrm{C}$, with $\mathrm{CaCl}_{2}$, for desiccation. A quantity of $0.5 \mathrm{~g}$ of dried material was then grinded using a TissueLyser II mixer mill (Qiagen) and the obtained powder was used directly for DNA extraction.

DNA extraction was performed using the CTAB-based method published by Lodhi et al. (1994) and improved by Pop et al. (2003). Our modification to the protocol was skipping the grinding of samples in liquid nitrogen, which were prepared as previously described.

The purity and concentration of DNA extracts were determined spectrophotometricaly, using the NanoDrop1000 instrument (NanoDrop Technologies).

The quality of extracted DNA was further tested by PCR, employing a SSR marker system in which amplification reactions were carried out 
Tab. 1. Plum tree cultivars selected for molecular analysis from the collection held at SCDP Vălcea

\begin{tabular}{ccccc}
\hline Andreea & CT 163 & Lăudatu & Presenta & Sâmbata 1 \\
\hline Alutus & Corval & Minerva & Păscoaia 4 & Tita \\
\hline Alina & Diana & Mici de Stoicești & Plumis & Tuleu gras \\
\hline Aurii de Bistrița & de Botești & Molive & Prun de Apold & Tuleu timpuriu \\
\hline Balada 4 & Dumbrăvești & Mirobolan Dwarf & Rival & Tuleu de Sinești \\
\hline Bărăgan 17 & P. Dumbrăvești & Miroval & Renclod de Caransebeș & Topval \\
\hline Boambe de Leordeni & Flora & Oltval & Roșior văratec & Troianu 6 \\
\hline Buburuz & Gras ameliorat & Oltenal & Record & Troianu 9 \\
\hline Carpatin & Gogoșele Otășău 3 & Oteșani 1 & Roz de Densus & Troianu 10 \\
\hline Centenar & Gogoșele Otășău 5 & Oteșani 8 & Roze tari & Troianu 11 \\
\hline Călugărești T2 & Gogoșele Otășău 11 & K5 & Romandreea & Vâlcean \\
\hline Călugărești T1 & Grase de Peșteana & Pescăruș & Sâmbata 2 & Vânăt românesc \\
\hline Corcoduș de & Gogoșele de & Porumbele & Sâmbata 4 & Voinești B \\
Sâmburești & Călimănești & Pinval & Scolduș & Vânăt românesc T3 \\
\hline CS 2A P9 & Goldane negre & & &
\end{tabular}

as described by Struss et al. (2003), with some modifications. Reaction mixtures (total volume of $12 \mu \mathrm{L}$ ) consisted of $20 \mathrm{ng}$ template DNA, 250 $\mathrm{nM}$ of each primer (Generi BioTech), $1.5 \mathrm{mM}$ of $\mathrm{MgCl}_{2}, 200 \mu \mathrm{M}$ of dNTPs and $1 \mathrm{U}$ Taq polymerase (Promega). DNA amplification was carried out in a 96 well Gradient Palm-Cycler (Corbett Research). Depending on each primer pair, such reactions are run with a touchdown protocol of 30-35 cycles (denaturation at $94^{\circ} \mathrm{C}$ for $1 \mathrm{~min}$, annealing at $55-65^{\circ} \mathrm{C}$ for $1 \mathrm{~min}$, extension at $72^{\circ} \mathrm{C}$ for $1 \mathrm{~min}$ ), followed by a single extension at $72^{\circ} \mathrm{C}$ for $7 \mathrm{~min}$. Two PCR primer pairs were used: UCDCH-13 and UDP 96-001.

The outcome of the PCR amplification was assessed by electrophoresis on a $1.4 \%$ agarose gel (Sigma-Aldrich) in $1 \mathrm{X}$ TAE, at $0.29 \mathrm{~V} / \mathrm{cm}^{2}$ for 2 hours. The molecular marker used was $100 \mathrm{bp}$ DNA Step Ladder (Promega). Gels were visualized on a UVP Biospectrum AC Imaging System (UVP BioImaging Systems) after $0.5 \mu \mathrm{g} / \mu \mathrm{l}$ EtBr staining for $20 \mathrm{~min}$.

\section{RESULTS AND DISCUSSION}

Using $\mathrm{CaCl}_{2}$ as a desiccating agent was a very efficient approach in terms of costs and handling and, in combination with the incubation temperature of $4{ }^{\circ} \mathrm{C}$, it virtually removed the possibility of microorganism activity. Furthermore, this type of leaf samples is well suited for mixer mill grinding.
The concentration of extracted DNA varied between approximately 220 and $3850 \mathrm{ng} / \mu \mathrm{L}$, while the 260/280 ratio was between 1.8 and 2.2 for most of the samples. Only four samples had less than $500 \mathrm{ng} / \mu \mathrm{L}$ and almost half exceeded $1500 \mathrm{ng} / \mu \mathrm{L}$.

All DNA extracts performed well in the PCR experiment using the SSR marker system. Amplicons of appropriate length were identified in each sample analysed using the previously described protocol.

\section{CONCLUSION}

We consider that the DNA preparation procedure tested here is very effective in providing extracts well suited for SSR analysis.

Aknowledgement. This paper was published under the frame of PN-II-PT-PCCA-2013-2014, project no. 168/2014.

\section{REFERENCES}

1. Lodhi MA, Ye G-N, Weeden NF, Reisch BI (1994). A simple and efficient method for DNA extraction from grapevine cultivars, Vitis species. Plant Molecular Biology Reporter 12(1): 6-13. http://dx.doi.org/10.1007/bf02668658

2. Pop R, Ardelean M, Pamfil D, Gaboreanu IM (2003). The efficiency of different DNA isolation and purification in ten cultivars of Vitis vinifera. Bulletin USAMV ZB Series, 59:259-261.

3. Struss D, Ahmad R, Southwick SM (2003). Analysis of sweet cherry (Prunus avium L.) cultivars using SSR and AFLP markers. J. Amer. Soc. Hort. Sci. 128(6):904-909. 